\title{
When the boss is watching: how online life is changing the scope of management
}

\author{
Nannina Angioni
}

$\mathrm{N}$ owadays, an employer can get a virtual blueprint of their employees' lives. They can track an employee's every move, from the moment they arrive to the second they leave the workplace. Various tools track websites an employee visits, how much time he/she spends online and whether the computer sat idle during the day. Employers can even recreate every email, text and instant message an employee sends from certain devices. Is this new wave of employee monitoring too Big Brother, or just responsible business management?

Employee advocates tout privacy, proclaiming, correctly, that employees have privacy rights they do not check at the door when they show up to work. They argue that employees should feel free to air personal thoughts and grieve about workplace issues online without fearing their employer's watchful eye. They also argue that most employer monitoring is nothing more than a fishing expedition, intended to root out details an employer may find personally offensive to use it against the employee when later convenient.

On the other hand, employers argue that they not only have a right but indeed also a duty to monitor employees' online activity. They cite legitimate business purposes for doing so - increasing employee productivity, curtailing cyberbullying among co-workers, limiting the risk that employees download computer viruses and protecting company trade secrets, to name a few. Employers contend that these purposes also justify their decision to intervene and limit employees' social media and Internet usage whether on or off-duty.

Both sides of the argument, however, have risk. Employees must be sure that their online posts do not cross into illegal territory while employers face exposure for discrimination with an increased access to data. If an employer decides to monitor and take action regarding an employee's online activity, some ground rules should apply:

- Employers must be prepared to handle whatever they find and apply their rules fairly and consistently among employees. Do not go into online monitoring blind. Have a game plan regarding what you will do if you find certain information. And, whatever the plan is, apply your practices consistently among all employees. For example, if an employer discovers that two employees have disclosed client information online but decides to discipline only one of them, the company is setting
Nannina Angioni is Attorney-

Partner at Kaedian LLP,

Los Angeles, California, USA. 
itself up for a discrimination lawsuit.

- Employers should never ask employees for their login or password information. Employees have a privacy interest in their personal logins and passwords. Even if they are using social media at work, that does not give an employer the right to demand this personal information.

- Employees must protect confidential and trade secret information. An employee does not have an unfettered right to post anything and everything online, without consequence. An employer must protect its confidential information and trade secrets. If an employee violates this protection by publicly sharing such important information in an online forum, regardless of whether the employee is on-duty at the time of posting, an employer may rightly take adverse action.

- Employees must not use social media to harass or bully co-workers. Employers may also discipline employees who use social media to affect the workplace or other employees, in a negative way. Harassment can come in many forms. Employers have an obligation to protect their employees from such conduct, whether it occurs in person or via the Internet. If an employee chooses to use social media to harass, bully, discriminate or threaten his/her co-workers, an employer will and should take action.

- Employers should not't use broad sweeping prohibitions when regulating Internet activity. State and federal courts, in addition to the National Labor Relations Board, opine time and time again that employees have a protected right to engage in concerted activity online. This means that employees have a protected right to grieve workplace issues on the Internet and to encourage their co-workers take action to report and correct unlawful employer conduct. If an employer makes broad sweeping rules, banning Internet usage or social media sites indiscriminately, an employer could unintentionally prohibit protected activity and consequently face liability.

- Employers should use clear and narrow limitations when limiting Internet use. An employee should understand exactly what is allowed and what is prohibited. When an employer's limits on Internet usage are vague, employees may wrongly believe that protected speech is banned. An employer may quickly find itself on the receiving end of a lawsuit, explaining that a reasonable person should have interpreted its Internet policies a certain way. Such a position is less than ideal, particularly as gray areas are often construed against the employer.

- Employers should consider using an outside monitoring agency. Employers are human. People cannot help but think of information they know when making decisions. Employers can quickly learn private facts about an employee by gleaning social media profiles. For example, an employer may discover an employee's political affiliation, sexual orientation or plans to have a baby from online posts. Such information goes to an employee's protected status. And, if an employer makes an adverse decision after learning about such protected status, the employee may have grounds for alleging unlawful discrimination. An outside monitoring agency could be used to keep tabs on employees' online activity and, only if the employee engages in a non-protected violation, would the agency notify the employer. This way, an employer's decision-making process cannot be tainted by a broad-based access to private information.

Overall, for as many benefits as technology brings, there are just as many obstacles that we must all keep in mind as the employment landscape changes in its wake.

\section{Corresponding author}

Nannina Angioni can be contacted at: nangioni@kaedianllp.com 